\title{
Aiming higher: the consequences of progressive ambition among MPs in European parliaments
}

\author{
ULRICH SIEBERER ${ }^{1}$ AND WOLFGANG C. MÜLLER ${ }^{2}$ \\ ${ }^{1}$ Department of Politics and Public Administration \& Zukunftskolleg, University of Konstanz, Konstanz, Germany \\ ${ }^{2}$ Department of Government, University of Vienna, Vienna, Austria
}

\begin{abstract}
How ambitious are MPs in European parliaments and how does progressive ambition affect their strategies? We argue that progressively ambitious members of parliament try to generate individual visibility and seek the support of party leaders who decide on promotion while at the same time ensuring reelection by adjusting to electoral system incentives. Using novel data from a 15-country MP survey we show that progressive ambition is widespread in Europe and Israel. As hypothesized, progressively ambitious MPs are more likely to favor personal rather than party-centered electoral campaigns and to address the national or regional party leadership instead of their local party. Electoral system features and party ideology also have the theoretically expected effects.
\end{abstract}

Keywords: progressive ambition; members of parliament; electoral campaigning; electoral system

\section{Introduction}

Political parties have traditionally taken center stage in parliamentary research in European and other party democracies. In recent years, however, parliamentary scholars have paid increasing attention to individual behavior below the level of parliamentary parties, for example to questions of individual voting and party unity (Sieberer, 2006; Carey, 2007; Kam, 2009), party switchers (Heller and Mershon, 2009; O'Brian and Shomer, 2013), and the role of party factions (Cox et al., 2000; Giannetti and Benoit, 2009). This shift in focus resonates well with a theoretical emphasis on rational choice accounts that start from the preferences of individual actors (see Saalfeld and Strøm, 2014). Nonetheless, most work on parliamentary democracies still moves quickly to the level of political parties as corporate actors pursuing policy, office, and vote goals (Strøm, 1990; Müller and Strøm, 1999). This abstraction is useful for studying many situations in which parties can be conceptualized as more or less unitary actors, for example in coalition formation and legislative voting in contexts with constantly high levels of party unity.

However, treating parties as unitary actors neglects individual ambition as a central motivation of MPs. Several scholars have addressed divergent individual

* E-mail: ulrich.sieberer@uni-konstanz.de 
policy and vote preferences as causes of voting behavior, floor speeches, and committee assignments (e.g. Stratmann and Baur, 2002; Bernauer and Bräuninger, 2009; Sieberer, 2010, 2015; Proksch and Slapin, 2012; Debus and Bäck, 2014). In contrast, the effects of individual office goals beyond reelection to parliament - that is personal career ambition - have gained little systematic attention.

Ambition theory provides a clear theoretical starting point for studying how individual career goals affect parliamentary strategies and behavior. Originally developed in the United States (Schlesinger, 1966), ambition theory has only been used sparingly in the European context, probably because its individualistic focus does not square easily with the dominant role of political parties. However, recent claims of a personalization of politics and a weakening of political parties (Dalton and Wattenberg, 2000; Poguntke and Webb, 2005; Karvonen, 2010) warrants new attention to the question whether ambition theory can help explain parliamentary strategies and behavior in party democracies as well.

In this paper, we take a first step toward mapping types of ambition among European MPs and studying how progressive ambition affects MPs' strategies. We argue that progressively ambitious MPs have incentives to seek individual visibility and to orient their activities toward the party leadership that will ultimately decide about promotion to higher office. For this purpose, they should favor personalized campaigns and seek the support of the national or regional party leadership instead of focusing on party campaigns and the party at the local level. At the same time, all MPs, including the ambitious ones, have to secure reelection. Thus electoral system incentives should systematically affect MPs' preferences for personal campaigns and for targeting a specific level of the party. We test our hypotheses using the comparative MP survey PartiRep (Deschouwer and Depauw, 2014) and find strong support for our key hypothesis on progressive ambition and further hypotheses on electoral system incentives.

The paper proceeds as follows: The next section discusses the state of research on progressive ambition and identifies the gaps in this literature with regard to European democracies. Next we present our theoretical argument about the effects of progressive ambition and reelection incentives and derive testable hypotheses. The fourth section discusses the data and methods used. We describe progressive ambition among European MPs and test our hypotheses in the fifth and sixth sections and close by discussing perspectives for future research.

\section{The consequences of progressive ambition: The state of the art}

Ambition lies at the heart of many rational choice theories. The concept is central for office-seeking theories of electoral competition and coalition formation (e.g. Schumpeter, 1942; Riker, 1962) as well as for vote-seeking theories of electoral competition and parliamentary behavior (e.g. Downs, 1957; Mayhew, 1974). A comprehensive theory of political ambition was first articulated by Schlesinger (1966) who distinguishes three types of ambition among members of parliament: MPs 
with 'discrete ambition' seek political office for a limited term and plan to return to private life afterwards. MPs holding "static ambition" seek a long-term career in a specific office, for example a parliamentary chamber, without aiming for further advancement to other offices. Finally, MPs with "progressive ambition" try to move beyond their current position to higher offices in the future. ${ }^{1}$

Progressively ambitious MPs are at the heart of Schlesinger's theory. He expects such MPs to act not only on the basis of the demands of their current office but also to take into account how current actions affect their chances of attaining more attractive offices in the future. Thus, MP strategies are more complex than a model based solely on the reelection goal would predict. In the extreme case, a progressively ambitious MP can pursue actions that seem irrational if we fail to take future career ambitions into account, for example if she appeals to voters beyond her current constituency even though doing so endangers some support among current voters.

Research on progressive ambition can be roughly divided in two strands. The first one tries to explain progressive ambition and the decision of MPs to seek higher offices (e.g. Rohde, 1979; Abramson et al., 1987; Maestas et al., 2006 for the United States and Samuels, 2003 for Brazil). The second strand - the one we seek to contribute to in this paper - studies the effects of progressive ambition. Most research on this topic deals with voting behavior in the US Congress showing that progressively ambitious Congressmen and Senators vote in line with the preferences of the larger constituency they appeal to for future offices (Van der Slik and Pernacciaro, 1979; Hibbing, 1986; Treul, 2009) and are more active in sponsoring bills, offering amendments and making speeches (Herrick and Moore, 1993). Progressively ambitious House members are also shown to build a record of specialization but broaden their policy profile in the advent of running for higher office (Herrick and Moore, 1993; Victor, 2011). Finally, US state legislators aiming for higher offices spend more time on getting informed about constituents' views suggesting higher responsiveness to public opinion (Maestas, 2003).

Knowledge of the effects of progressive ambition is much more limited outside the United States. Several studies have addressed the role of ambition and institutional structures in shaping typical career paths, mostly outside of Europe (Epstein et al., 1997; Norris, 1997; Cox et al., 2000; Samuels, 2003; Micozzi, 2014). However, there are very few studies of how progressive ambition shapes legislative behavior in European democracies (but see Searing, 1994 and conceptually Strøm, 1997). As far as we can see, the only quantitative-comparative study analyzes how career ambitions affect voting behavior in the European Parliament that offers MPs the unique opportunity to aim for higher offices at the national or European level (Meserve et al., 2009). In line with ambition theory, MPs pursuing careers on the national level are less likely to vote with their European party groups, especially in

\footnotetext{
${ }^{1}$ Some scholars add the ambition to attain leadership positions within a single institution such as parliament (intra-institutional ambition) as an additional category distinct from static ambition (Herrick and Moore, 1993).
} 
the advent of national elections, and are more likely to vote against strengthening European institutions.

Quantitative studies on progressive ambition in national and regional legislatures in Europe are completely absent. Thus, we lack both comparative data on the amount of progressive ambition among European MPs and systematic analyses of its consequences. This paper contributes to filling these gaps by providing a descriptive account of ambition types in 72 national and subnational legislatures in $14^{2}$ largely European party democracies and by studying the effects of progressive ambition on legislators' strategies.

Before turning to our theoretical explanation, we have to address the question of how to measure ambition and its consequences because these methodological decisions influence the choice of the dependent variables we seek to explain theoretically. Two distinct approaches are used to measure ambition: Most studies ascribe progressive ambition to those legislators who run (with or without success) for higher office at some point in their career (Hibbing, 1986; Herrick and Moore, 1993; Cox et al., 2000; Treul, 2009; Victor, 2011) while others rely on legislators' statements about their future career plans in surveys (Maestas, 2003; Maestas et al., 2006). Conceptually, the survey-based approach is superior because ambition refers to an attitude of MPs. The ultimate decision to run for higher office is influenced by a multitude of additional factors, most importantly the likelihood of success. If we rely on actual behavior as a proxy for ambition, progressively ambitious politicians facing an adverse opportunity structure, and thus deciding against pursuing their ambition, would be mistaken as harboring static ambitions (see Maestas, 2003). Thus, survey-based measures can be seen as more valid indicators for the concept of ambition than behavioral proxies.

With regard to the effects of ambition, we can also distinguish two general measurement approaches: MP activities such as roll call voting, speeches, bill sponsorship, and amendments on the one hand, and attitudinal measures in surveys on the other hand. Both approaches have their pros and cons. Behavioral measures capture the phenomenon we are ultimately interested in most directly. On the other hand, the link between ambition and behavior is affected by intervening variables such as institutional rules and situation-specific competitive conditions. Furthermore, it is extremely difficult to find comparable indicators of individual parliamentary behavior because the institutional regulation of parliamentary activities and established patterns of usage vary considerably across countries.

Attitudinal measures, on the other hand, capture what deputies consider their best general strategies and thus to some degree abstract from the specific decisionmaking context preceding actual behavior. Measuring both ambition and its consequences on the level of attitudes reduces the potential for confounding factors and increases the internal validity of the argument. On the downside, however, we cannot be sure to what extent the attitudes MPs state are actually translated into

\footnotetext{
${ }^{2}$ The relevant survey question was not asked in the Netherlands reducing the number of countries in our sample to 14 .
} 
behavior. Furthermore, these measures suffer from the usual problems of MP surveys such as low return rates, potential unrepresentativeness of the realized sample, and social desirability.

In this paper, we rely on attitudinal measures of the effects of ambition for both conceptual and pragmatic reasons. Conceptually, we prefer to measure both our dependent and key independent variables on the same level as attitudes in order to ensure the internal validity of our tests. Pragmatically, available data from the PartiRep MP survey can be used to measure both MPs' ambition and their stated strategies. This data set contains only a few variables that capture MP behavior and these variables are fraught with problems of missing data and comparability across parliaments, and adding new behavioral data is not feasible due to the anonymity of the survey.

Obviously, the reliance on survey data limits the conclusions we can draw on MP behavior. Nonetheless, we think that our analysis on the attitudinal level is a useful and necessary first step in assessing the effects of progressive ambition, given the scarcity of previous research on the topic outside the United States. Not finding any relationships on this level would largely close the book on the question, whereas supportive findings encourage future efforts to collect suitable behavioral data to test the link between attitudes and behavior. We further discuss the methodological problems associated with the survey approach in the data section and return to the question of behavioral consequences in the conclusion.

\section{The effects of progressive ambition in parliamentary democracies: Theory and hypotheses}

\section{Progressive ambition and the need for individual visibility}

The key theoretical claim of ambition theory states that progressively ambitious MPs try to advance their careers by choosing strategies and behaving in ways that make promotion more likely. ${ }^{3}$ Thus, the main question becomes what strategies best serve this purpose. We argue that the strategies progressively ambitious MPs pursue depend on both their most promising pathways to higher offices in the future and the immediate need to retain their current mandate.

Regarding future promotion, we can expect ambitious MPs to seek the attention and support of those actors who control access to the sought-after higher positions. In Schlesinger's US-based theory, those actors are voters, more specifically the larger constituency to which a politician appeals when running for the Senate, a governorship, or even the presidency. In parliamentary democracies, however, political parties, not voters, are the most important targets for ambitious MPs (Müller, 2000). In most cases, parties decide on positions on party lists in

\footnotetext{
${ }^{3}$ Most likely, MPs' ambition for higher offices is instrumental for reaching intrinsically pursued goals such as affecting public policy or enjoying material and immaterial office benefits and other rents extracted from high positions. Analytically, however, it is useful to focus on the immediate office goals irrespective of the underlying intrinsic motivations.
} 
proportional representation systems and official endorsement and support of candidates in SMD systems, they distribute leadership positions in parliament, they de facto distribute cabinet positions, and they control access to (or at least act as gatekeepers for) other high offices such as the presidency, constitutional courts, and often even publically controlled sectors of the economy. 4

MPs use various tools to draw the attention and support of their parties. To name just a few, MPs can do legislative work in the plenary, in committees, and in the parliamentary party group, work actively in the party organization, show effort in electoral campaigning, seek media presence, build up policy expertise, and foster bonds with interest groups surrounding the party. The costs and benefits of these options depend heavily on institutional rules, party organization and various other context conditions. Thus, they cannot be spelled out completely in abstract terms.

However, there is one common feature that unites progressively ambitious politicians across time and space: The need to get the attention of those actors who decide on promotion. Ambitious politicians must find ways to stand out from the crowd of co-partisans to position themselves in intra-party competition for scarce higher positions. Standing out does not imply creating a profile against the party. Obviously, this is rarely a promising strategy for advancement in party-centered systems. Instead, ambitious MPs try to add a positive personal profile for example by presenting themselves as committed, energetic, hard-working, knowledgeable, bringing in new ideas and able to convince voters. MPs with such personal attributes become an electoral and legislative asset for their party and should thus have better career prospects than anonymous party soldiers.

Our analysis focuses on two central means for creating individual visibility: personalized election campaigning and addressing the party leadership at a higher level. Personal campaigns are attractive for several reasons. Via personal campaigning, MPs build up an individual profile and demonstrate their ability to convince voters (possibly also beyond the party faithful) to support them as persons. ${ }^{5}$ Furthermore, they can gain visibility in the media and the public which may well be helpful in intra-party competition. Second, progressively ambitious MPs specifically seek the attention of those actors who decide on future advancement. In party-centered systems, these are usually the party leaderships at the national or (for MPs pursuing subnational careers) the regional level rather than the local party. Progressive ambition thus gives MPs incentives to pursue a personal campaign and to target the party leadership at a higher level.

At the same time, even progressively ambitious MPs usually have to retain their current mandate. In parliamentary democracies, a parliamentary mandate is often a

\footnotetext{
${ }^{4}$ Of course some empirical cases diverge from this general statement, for example by giving party members a say in candidate selection (Shomer, 2014). We include this factor in the empirical analysis below.

${ }^{5}$ Note that it does not matter for MPs whether voters ultimately cast their ballots based on the MP's personal characteristics or based on the party label. In either way, MPs can claim credit for the success because they can credibly tie it to themselves as persons.
} 
formal or at least informal condition for advancement to higher offices such as government positions. Electoral defeat or even deselection as parliamentary candidate can put an effective end to further ambitions. Thus, the strategies of all MPs (except those planning to leave politics for good) are also oriented to the more immediate goal of reelection to parliament (Mayhew, 1974; Strøm, 1997). In that sense, progressive ambition is an add-on to, rather than a substitute for, static ambition in parliamentary systems.

The reelection goal implies that MPs react to institutional incentives created by the electoral system. We discuss several specific expectations in the next section. The effects of electoral system variables on the strategies of MPs are interesting in their own right. Furthermore, we have to control for reelection-based incentives when analyzing the effects of ambition on MPs' strategies.

\section{Hypotheses}

In this section, we derive testable hypotheses from our theoretical argument. The expected effects of progressive ambition were discussed in detail above and thus do not require much explanation here. Additional control variables without clear theoretical expectations are discussed in the data section below.

Progressively ambitious MPs try to create visibility and support from those actors most important for attaining higher offices. Thus, they should be more inclined toward personalized campaigning and be more likely to appeal to the party leadership at the higher level than MPs with static or discrete ambition. This leads to the following two hypotheses:

HYPOTHESIS 1A: Progressively ambitious MPs are more likely than other MPs to favor a personal instead of a party-centered campaign.

HYPOTHESIS 1B: Progressively ambitious MPs are more likely than other MPs to favor seeking support of the national/regional party leadership instead of the local party.

Second, we argue that all MPs choose their strategies based on electoral system incentives affecting reelection. In line with established theory, we expect three features of the electoral system to affect MPs' strategies regarding personal campaigning and their orientation toward a particular level of the party. The most obvious variable is the magnitude of the district in which MPs are elected. Single member districts give all MPs incentives to present themselves as individuals to build a personal vote. Larger districts, by contrast, make it more likely that individual MPs are perceived solely as members of their parties and thus have few incentives to present themselves as individuals (Cain et al., 1987; Zittel and Gschwend, 2008; André et al., 2014). ${ }^{6}$ We focus on the binary distinction between single member and

\footnotetext{
${ }^{6}$ Carey and Shugart (1995) argued that the effect of district magnitude on personal vote seeking should differ depending on whether candidates of the same party compete against each other. A recent study of
} 
multi member districts because it provides clear theoretical expectations whereas one may doubt whether differences on higher levels, say between districts of 17 and 18 members, still affect personal vote seeking. However, we include the continuous variable 'district magnitude' in the robustness checks below. Turning to the second dependent variable, MPs running in SMDs should respond primarily to their local party which tends to be in charge of candidate selection (Shomer, 2014: Figure 4) and bears the burden of constituency campaigning on the ground. Thus:

HYPOTHESIS 2A: MPs elected in single member districts are more likely than other MPs to favor a personal instead of party-centered campaign.

HYPOTHESIS 2B: MPs elected in single member districts are more likely than other MPs to favor seeking support of the local party instead of the national/regional party leadership.

Second, electoral systems allowing voters to cast votes for individual candidates instead of parties give MPs incentives to pursue a personal campaign (Carey and Shugart, 1995; Karvonen, 2010; André et al., 2014). While such a campaign is mainly designed to win votes for the party in SMD systems, it entails an additional element of intra-party competition in proportional systems with open lists and the Single Transferable Vote system because in these constellations candidates can improve their electoral prospects by outscoring co-partisans (Martin, 2010). The existence of candidate voting, on the other hand, does not generally imply an orientation toward a specific level of the party because the locus of candidate selection differs widely in electoral systems with candidate voting (compare e.g. locally selected candidates in SMDs with nationally selected, open party lists). Thus, we have a clear theoretical expectation only regarding one dependent variable:

HYPOTHESIS 3: MPs elected in systems with candidate voting are more likely than other MPs to favor a personal instead of party-centered campaign.

A third relevant variable is the use of party primaries for selecting parliamentary candidates. Primaries introduce an element of intra-party competition in the run-up to general elections which forces candidates to build a personal reputation and to seek support on the local level. ${ }^{7}$ Thus:

HYPOTHESIS 4A: MPs selected via primary elections are more likely than other MPs to favor a personal instead of party-centered campaign.

personal vote seeking based on the PartiRep data we use does not find such an effect but instead shows that district magnitude decreases personal vote seeking throughout (André et al., 2014). Based on this finding we do not pursue the interactive argument advanced by Carey and Shugart.

7 The process of candidate selection varies beyond the extreme case of primary elections (Hazan and Rahat, 2010). We focus on primaries because they provide particularly strong incentives for building a personal reputation and local support. We also test the impact of additional aspects of candidate selection in the section on robustness tests. 
HYPOTHESIS 4B: MPs selected via primary elections are more likely than other MPs to favor seeking support of the local party instead of the national/ regional party leadership.

In addition to progressive ambition and electoral system incentives, party ideology can affect the attitudes of candidates toward personalized campaigns. Members of parties with a collectivist ideology should focus more on party campaigns than members of parties with a more individualistic culture. This effect can stem from personal conviction and socialization of candidates or can be strategic if candidates expect that party members and voters dislike a candidate-centered campaign. There is no reason to expect that a collectivist ideology is systematically related to targeting a specific party level. Thus:

HYPOTHESIS 5: MPs from parties with a collectivist ideology are less likely than other MPs to favor a personal instead of a party-centered campaign.

\section{Data and methods}

We use data from the PartiRep survey to describe ambition among European legislators and to test our hypotheses on its effects. This comparative MP survey was conducted by an international team in 15 largely European countries between March 2009 and January 2011. ${ }^{8}$ The survey addressed all members of the 15 national parliaments and various subnational parliaments in nine of the 15 countries. Response rates ranged from $46.7 \%$ (Belgium) to $7.1 \%$ (Italy) for the national MPs (mean 23.8\%) and from $40.4 \%$ (Portugal) to $21.5 \%$ (Switzerland) for the regional MPs (mean $31.0 \%$ ). Further details on the survey are described in Deschouwer et al. (2014).

Despite the low return rates, the overall sample is quite representative of the population of MPs surveyed with regard to such variables as government participation, level of government, gender, and party with Duncan dissimilarity index values of eight or less (Deschouwer et al., 2014: 10-11). ${ }^{9}$ However, differences in return rates could still lead to biased inferences if the propensity to participate in the survey was tied to the ambition of MPs, for example because confessing progressive ambition is considered inappropriate in some countries. Such a social desirability bias is not very likely because full anonymity was guaranteed to all respondents. Furthermore, we can provide some indirect empirical indications on the size of the problem by analyzing whether return rates are correlated with the share of MPs in the chamber who report progressive ambition. If ambitious MPs systematically refused to participate in the survey, reported ambition should increase with turnout.

\footnotetext{
8 The countries included are Austria, Belgium, France, Germany, Hungary, Ireland, Israel, Italy, Netherlands, Norway, Poland, Portugal, Spain, Switzerland, and the United Kingdom.

${ }^{9}$ Deviations are larger for individual countries. However, such deviations are less critical for our purposes as we do not run country-level analyses.
} 
The two variables are only very weakly and statistically insignificantly related with a correlation of $r=-0.09$. While there are of course many reasons for not responding to the survey that are unrelated to ambition, the lack of a relationship suggests that return rates do not massively bias our findings. Furthermore, any remaining bias due to social desirability concerns should be constant for parties within a specific parliament (e.g. Labour in the British House of Commons or the Lega Nord in Lombardy) and would thus be picked up by random intercepts in the empirical analysis (see below).

To measure ambition as our key variable of interest, we rely on the answers to the following survey question: 'If it was up to you alone, where would you most like to be five years from now?' Respondents were given a choice of 10 options plus an additional fill-in space for open answers. ${ }^{10}$ Note that the qualifier 'if it was up to you alone' urges respondents to state their future career goals independent of their perceived chances of reaching these goals. Thus, the question is designed to tap directly into the underlying concept of ambition instead of capturing a mixture of ambition and the institutional opportunity structure MPs face.

Based on this question, we distinguish three types of ambition. We code an MP as progressively ambitious if s/he states the goal of becoming a member of a national or regional government, president, governor, and for regional MPs also member of the national parliament or Senator and if s/he does not currently hold this office. An MP stating one of these goals is coded as progressively ambitious irrespective of additional answers. We code MPs as holding static ambition if they aim to remain MPs on the same level, want to become mayors or members of the European Parliament and, for national MPs, Senators, or want to retain a ministerial office they currently hold. Finally, we code MPs who wish to retire from public life in the category 'leave office'. This category is similar but not equivalent to Schlesinger's discrete ambition because we lack information on how long such MPs have been serving in parliament. Finally, we assign all open answers individually to the types of ambition. ${ }^{11,12}$ For most analyses, we dichotomize this three-category variable by creating a dummy variable Progressive Ambition. In the section on robustness tests, we also employ a narrower operationalization in which only MPs aspiring to executive

10 The options were: member of the national parliament; member of a regional parliament; Senator; member of the national government; member of a regional government; member of the European Parliament; provincial governor or head of the regional council; mayor; president; retired from public life; and an open category 'other' with the opportunity to fill in a more specific answer. Some of the options were only included in countries where they are applicable.

11 All MP using the 'other' option also mention at least one of the alternative options based on which we initially code their ambition. Only five MPs are coded as progressively ambitious in a second step only based on the position they mention in the open answers. The specific ambitions mentioned in this category are highly diverse, do not cluster around specific offices or occupations, and rarely refer to important positions.

${ }^{12}$ We code MPs stating intra-institutional ambitions regarding leadership offices via the open answers in the category of static ambition because we lack systematic data on such intra-institutional ambition. We cannot capture intra-executive ambitions such as aiming for a more prestigious cabinet post due to a lack of fine-grained data. 
office (national or regional minister, provincial governor, president) are treated as progressively ambitious and a broader one that treats aiming for the office of mayor as progressive ambition. A descriptive breakdown of ambitions stated for the different offices by country and level of government is available in the online appendix.

Our two dependent variables are derived from survey items asking MPs how they would allocate scarce resources between pairs of competing goals. These items are introduced by the following general question: 'To retain their seat in Parliament, Members of Parliament often face hard choices. How would you choose to allocate your limited resources? Would you choose to spend more effort and money on achieving the goal on the left-hand side, would you choose to spend more effort and money on the goal on the right-hand side, or would the allocation of resources to both goals be about equal?' The framing of this question toward reelection is somewhat problematic for our purpose of measuring career-oriented strategies in general. However, we argue that - in the absence of other survey questions - the stated attitudes of MPs can also be used to study the effects of ambition in the European context, where ambitious MPs have to secure reelection to remain in the pool from which appointments to higher offices are made. A personal campaign or a focus on a particular level of the party can serve multiple purposes at once such as building electoral support and creating individual visibility in pursuit of career advancement. Thus, we assume that respondents answer this question based on the general position they take on the stated trade-off. Based on this assumption, we employ this data to test both the ambition-based and the reelection-based hypotheses advanced above.

For the variable Personal Campaigning, respondents are presented a five-point scale with the extreme positions 'on a personal campaign' and 'on a party campaign'. ${ }^{13}$ For the variable High Party Level Targeted, the scale has the extreme positions 'to obtain the regional/national [depending on the parliament an MP serves in; the authors] party's support' and 'to obtain the local party's support'. We recode both variables in such a way that high values indicate the strategy we expect progressively ambitious MPs to pursue, that is a preference for personal campaigns and an orientation toward the national/regional party.

The operationalizations of the electoral system variables are straightforward. Single Member District is a binary variable coded 1 for MPs elected in such districts and 0 otherwise. Candidate Vote is a dummy variable coded 1 if voters can cast votes for individual candidates and 0 otherwise. The variable Primary has the value 1 if candidates are selected via party primaries and 0 otherwise. For mixed electoral systems, all electoral system variables are coded on the level of individual MPs reflecting the tier in which he or she was elected. The three electoral system variables are only weakly correlated and thus do not cause problems with multicollinearity. ${ }^{14}$ The variable Collectivist Ideology is a binary variable based on

\footnotetext{
13 André et al. (2014) use the same variable to analyze the effects of electoral rules on personal voteseeking.

14 The strongest correlation exists between single member districts and primaries with $r=0.38$.
} 
the party family an MP's party belongs to (Ozbudun, 1970). We code the following parties as collectivist: communist parties, socialist/social democratic parties, religious parties, far-right/anti-immigrant parties, green parties, and regional/ethnic parties. By contrast, liberal, conservative, Christian Democratic, agrarian and single-issue parties are coded as individualist. The few parties not assigned to one of the families are coded based on their qualitative description in the PartiRep data set. ${ }^{15}$

MPs' attitudes toward personal campaigning and the level of the party they target may be affected by additional factors for which we lack clear theoretical expectations. We include these factors as control variables. On the level of parliament, the amount of attractive career opportunities may affect the decision of MPs to pursue personal campaigns and to target a specific level of their party. We control for the Executive Opportunity Structure in a system using the ratio of cabinet positions to the total number of MPs. The higher this ratio is, the better are the chances for ambitious MPs to acquire the most sought-after offices in parliamentary democracies. ${ }^{16}$ In the section on robustness checks, we also employ an alternative measure of the opportunity structure within parliament. ${ }^{17}$ On the level of individual MPs, the dummy variable Leader identifies MPs holding one of the following offices: Speaker or deputy speaker of parliament, leader of a parliamentary party group, chair of a permanent committee, or one of up to three country-specific leadership offices including cabinet positions contained in the data set. Leaders may differ in their level of ambition and, as they exert a stronger influence on the party position, also in their attitudes toward personal campaigning and focus more strongly on higher party levels. Furthermore, we use the following individual-level control variables: Female MPs who might pursue different career patterns and have displayed different types of ambition (Norris, 1997); the age of an MP captured by his or her Year of Birth because both future career ambitions and preferred campaign style could depend on age; Seniority measured as the year an MP was first elected to the chamber he or she currently serves in because more senior MPs could show different patterns of ambition as well as different campaign styles; and a dummy variable Regional identifying subnational instead of national assemblies because regional MPs may be more ambitious and subnational campaigns may differ from national ones. ${ }^{18}$

\footnotetext{
15 In the robustness tests below we also estimate models based on the different party families instead of the binary variable collectivist ideology.

16 The data on the number of cabinet positions is taken from the ParlGov database (Döring and Manow, 2012) and, for regional parliaments, Wikipedia. If the number of cabinet positions changes over the period of the survey (2009-11), we rely on the number in the cabinet that was in office for the longest share of time.

For purely presentational reasons, this ratio is multiplied by the factor four. This linear transformation does not affect the substantive results in any way but ensures that the range of the estimated coefficients is roughly similar.

17 Another relevant aspect of the opportunity structure is the chances of an MP's party to participate in the cabinet. However, systematically measuring these prospects for more than 300 parties in 68 , mostly subnational parliaments is not feasible in the context of this paper.

18 The variables Year of Birth and Seniority are only moderately correlated $(r=0.42)$ and thus do not pose multicollinearity problems. Models using only one of the variables yield substantially equal results.
} 
Three methodological issues arise in testing our hypotheses. First, the data structure is hierarchical consisting of MPs who are nested in parliamentary parties that are themselves nested in parliaments. ${ }^{19}$ While Progressive Ambition as our main variable of interest varies on the level of individual MPs, other variables are specific to parliamentary parties (Collectivist Ideology, Primary) or the entire parliament (Candidate Vote, and with the exception of mixed electoral systems $S M D)$. Even though we include explanatory variables on all three levels, we will certainly not capture all party- and parliament-specific variation. Thus, observations within a specific party group and a specific parliament, respectively, will most likely not be conditionally independent. We account for this clustering by using a multilevel model with three hierarchical levels (MPs, party groups, parliaments) and include random intercepts at the party group and parliamentary level (see e.g. Gelman and Hill, 2007). These random intercepts capture differences in the dependent variables that are specific to party groups and parliaments, respectively and which are not accounted for by our explanatory variables, for example differences in the parliament-specific opportunity structure beyond the availability of cabinet posts.

Second, we treat our dependent variables as metric and use a linear model. Both variables are measured on a five-point scale for which only the extremes are labeled, thus encouraging a metric interpretation by the respondents. We report ordinal models in the section on robustness tests.

Finally, the unequal return rates across party groups and parliaments raise the question of weighting. For the descriptive analysis, we use weights to make descriptive figures comparable across party groups and parliaments. In the explanatory analysis, on the other hand, we do without weights because our theoretical focus is on individual MPs, not party groups or parliaments, and because lower-level weights, conditional on the selection of the higher-level cluster that would be required for the multilevel model, are not available in the data set. The principal investigators of the PartiRep survey also state that unequal return rates should be less problematic for explanatory analyses interested in relationships between variables (Deschouwer et al., 2014: 11). Furthermore, party-specific and parliament-specific differences (which may partly result from different return rates) are captured by the random intercepts on the two upper levels.

\section{Descriptive patterns of ambition among European MPs}

Our data allows the first broad comparative description of career ambition among European MPs. Note that the measure captures MPs stated career goals, and not necessarily their expectations to be successful in their quest. Of the $2045 \mathrm{MPs}$ answering this question, just over half $(53.8 \%)$ state static ambition, while $27.6 \%$ are classified as progressively ambitious. The remaining $18.6 \%$ intend to leave

\footnotetext{
${ }^{19}$ Countries are not a relevant level because institutional variables such as the electoral system vary between different national and subnational parliaments within a country.
} 


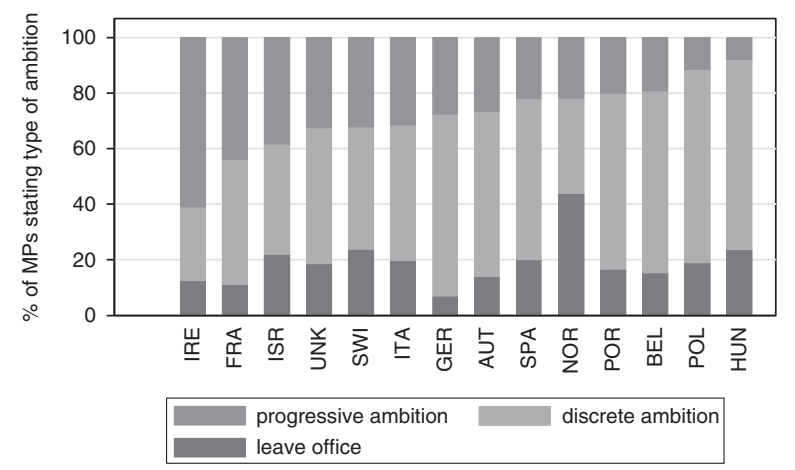

Figure 1 Types of ambition among European MPs by country (national and regional level). Data are weighted with party weights.

public office. Figure 1 shows the distribution of the three types of ambition by country. ${ }^{20}$ The share of MPs with progressive ambition varies between roughly $60 \%$ in Ireland and less than $10 \%$ in Hungary. ${ }^{21}$ Static ambition is the modal category in all countries except Norway (where retirement is the most frequently chosen option) and Ireland and Israel where progressive ambition dominates. Figure 2 further distinguishes between countries and the level of government, focusing on progressive ambition as the theoretically most important type of ambition.

The figures show two general patterns. First, progressive ambition tends to be more widespread among MPs in regional assemblies compared to their colleagues in the national parliament. The differences are particularly pronounced in Switzerland, Spain, Italy, and Belgium, while there are almost no differences in Austria and the United Kingdom. This pattern is quite intuitive as regional legislators have a larger number of higher offices to aim for. Furthermore, the regional level is, in many countries, considered a starting point for a national political career promising more policy influence and higher material rewards of office.

Second, the large share of progressively ambitious national MPs in Ireland, Israel, France, and the United Kingdom makes substantive sense. The parliaments in Ireland and Israel are relatively small assemblies in which the ratio of cabinet offices to seats - and hence the institutional opportunity structure - is very favorable (e.g. Martin, 2014). A similar argument can be made for the United Kingdom with its elaborate structure of leadership positions, both on the government and the opposition sides (Searing, 1994). The French case, on the other hand, illustrates

\footnotetext{
${ }^{20}$ The question on future career goals was not asked in the Netherlands where the survey was conducted right before an election.

${ }^{21}$ The exact percentages have little meaning given the sometimes small numbers of respondents from individual countries.
} 


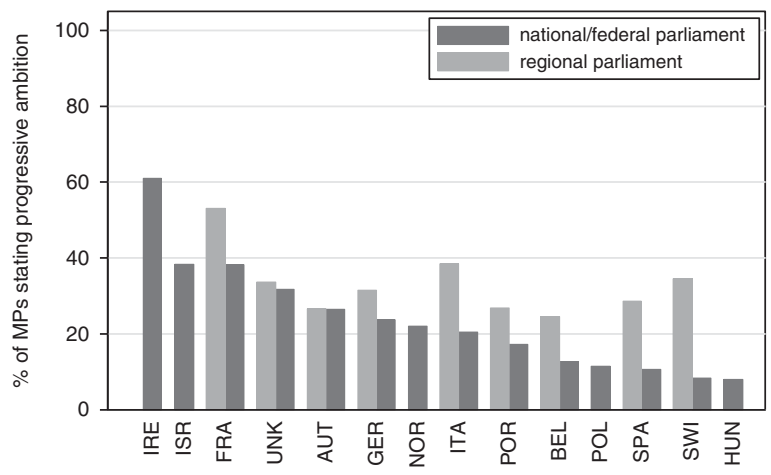

Figure 2 Progressive ambition among European MPs by country and level of government. Data are weighted with party weights.

a different context favoring progressive ambition: An institutionally powerless parliament as the Assemblée nationale forces ambitious politicians to look for other venues to advance their careers.

\section{Explanatory analysis}

Do differences in ambition lead MPs to choose different strategies regarding personal campaigning and their orientation toward different levels of their party? As detailed above, we test our hypotheses using a three-level linear regression model with random intercepts at the levels of party groups and parliaments. Our analyses are based on 1726 observations for which we have complete data on all variables. These 1726 MPs come from 318 different party groups in 68 parliaments, thus providing enough observations on the upper levels for multilevel modeling. Descriptive statistics for all variables are given in Table 1.

The estimation results for the two models are displayed in Figure 3. The graph shows the estimated regression coefficients for the fixed part of the model, along with $90 \%$ and $95 \%$ confidence intervals. The expected direction of the coefficients for those variables on which we formulated explicit hypotheses is reported above the estimates with a zero, indicating that we do not expect a significant effect and with a question mark indicating no expectation about the direction. All models were estimated in Stata 13 using the xtmixed command. A table listing the precise estimates is available in the appendix.

The statistical models provide strong evidence for the hypothesized effects of progressive ambition. Progressively ambitious MPs are significantly more likely to express a preference for a personal instead of a party-centered campaign and to target the party leadership at the higher level rather than their local party. Controlling for the other variables in the model and the random intercepts on the 
Table 1. Descriptive statistics

\begin{tabular}{|c|c|c|c|c|}
\hline & Mean & std. dev. & Minimum & Maximum \\
\hline Personal campaigning (dep. var.) & -3.22 & 1.16 & -5 & -1 \\
\hline High party level targeted (dep. var.) & -3.20 & 1.05 & -5 & -1 \\
\hline Progressive ambition & 0.27 & 0.45 & 0 & 1 \\
\hline Single member district & 0.16 & 0.37 & 0 & 1 \\
\hline Candidate vote & 0.67 & 0.47 & 0 & 1 \\
\hline Primary & 0.15 & 0.36 & 0 & 1 \\
\hline Collectivist ideology & 0.53 & 0.50 & 0 & 1 \\
\hline Leader & 0.20 & 0.40 & 0 & 1 \\
\hline Executive opportunity structure ${ }^{a}$ & 0.36 & 0.25 & 0.10 & 1.18 \\
\hline Regional & 0.54 & 0.50 & 0 & 1 \\
\hline Female & 0.30 & 0.46 & 0 & 1 \\
\hline Year of birth & 1959.05 & 9.96 & 1930 & 1986 \\
\hline Seniority & 2002.34 & 6.40 & 1973 & 2011 \\
\hline
\end{tabular}

Based on all observations used in the regression analyses $(N=1726)$.

${ }^{a}$ For presentational purposes in the regression results, the ratio of cabinet posts over parliamentary seats is multiplied by the factor 4 . This explains the maximum ratio of 1.18 . Without the transformation, the variable ranges from 0.026 to 0.29 with a mean of 0.09 .

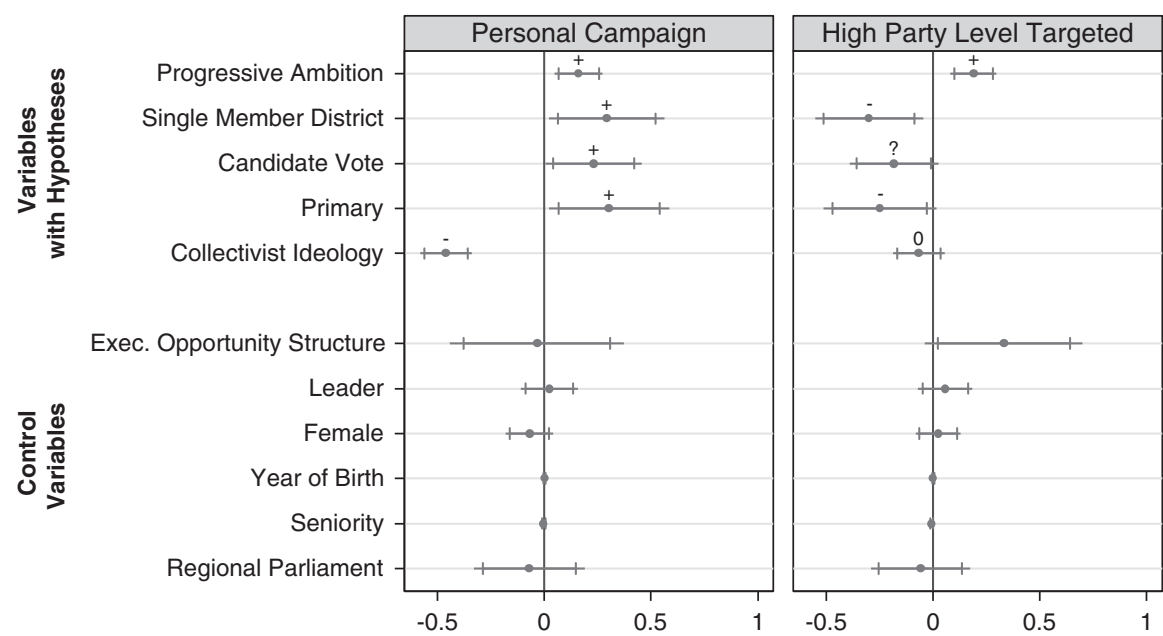

Figure 3 The effects of progressive ambition and electoral system incentives on attitudes toward personal campaigning and the party level targeted by European MPs. Coefficients for the fixed part of the model with $90 \%$ and $95 \%$ confidence intervals. The hypothesized direction of the effects is indicated by + and - .

party and parliament level, progressively ambitious MPs are predicted to score 0.16 points higher on the scale for personal campaign and 0.19 points higher for the party level targeted. As both dependent variables are measured on a five-point scale 
with answers clustering in the middle of the scale, this effect is not huge but clearly not negligible. ${ }^{22}$

The analyses also corroborate the hypotheses on electoral system incentives. As expected, MPs elected in single member districts significantly prefer more personalized campaigns and put stronger emphasis on gaining the support of their local parties. The same is true for MPs facing primaries at the candidate selection stage. Also in line with our hypotheses, MPs favor more personalized campaigns if voters can cast their votes for candidates directly and not only for party lists. Finally, we find that candidate voting is associated with a focus on the local party. This finding is probably due to the fact that most cases of candidate voting stem from single member districts rather than open party lists with a strong influence of preference votes.

We also find strong support for the party-level hypothesis that MPs from parties with a collectivist ideology are less inclined toward personal campaigns. In fact, this variable has substantively the strongest effect in the model decreasing support for personal campaigns by 0.46 points. As expected, a collectivist party ideology does not affect the attitudes of MPs on seeking support from the local or national/ regional party. Among the control variables, we find only one statistically significant effect: A more favorable executive opportunity structure leads MPs to focus more on the party leadership at the higher level. This finding makes sense theoretically as cabinet posts are distributed by the party leadership rather than the local party.

The random part of the model provides strong evidence for the expected clustering in the data. The multilevel models provide a significantly better fit to the data compared to ordinary linear regression models. The standard deviations of the random intercepts on the level of parliaments $(0.34$ and 0.29 , respectively, for the two dependent variables) and of party groups within parliaments $(0.22$ and 0.24 ) are substantively large and highly significant in all models. For the purpose of this paper, the random intercepts are sufficient to assure that the estimates of our explanatory variables are unbiased. However, exploring the party-level and parliament-level sources of this variation more deeply is an interesting perspective for future research.

\section{Robustness tests}

We estimate various additional model specifications to ensure the robustness of our findings. First, we test whether the effect of progressive ambition depends on reelection incentives by including interaction terms between ambition and the three electoral system variables. Theoretically, one could expect ambitious MPs to focus even more on personalized campaigns if the electoral context also encourages such

$2275.7 \%$ and $81.2 \%$ of the answers, respectively, fall in the three middle categories for the two dependent variables. 


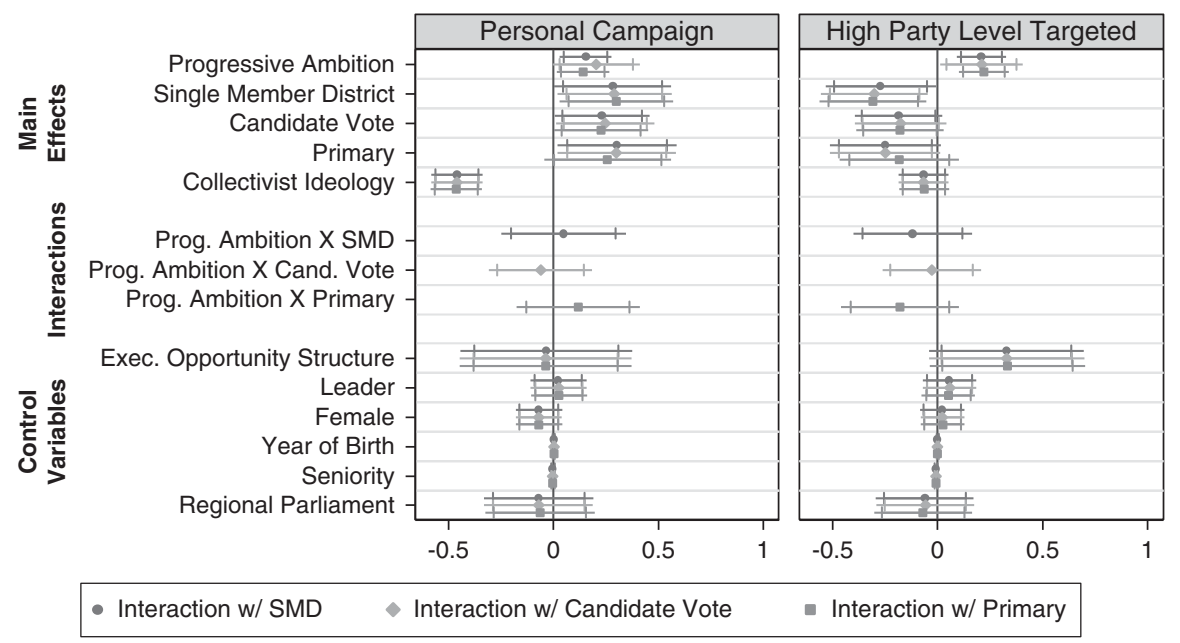

Figure 4 Robustness tests I: Interactions between ambition and electoral system incentives. Coefficients for the fixed part of the model with $90 \%$ and $95 \%$ confidence intervals.

behavior, that is in systems with single member districts, candidate vote and primaries. Conversely, ambitious MPs in such systems are torn between seeking local support for reelection and targeting the higher level of their party for advancement which might lead to a weaker effect of ambition.

Figure 4 displays the estimates for models with one interaction term each between ambition and one of the three electoral system variables. These models find no empirical support for these expectations. All interaction terms are statistically insignificant and the main effects of progressive ambition and the respective electoral system variable retain their significance level and approximate size. Thus, we can conclude that ambition and reelection concerns have purely additive effects on MPs' attitudes toward personal campaigning and the targeting of a specific level of their party.

Second, we run several robustness tests that employ different operationalizations of key variables, introduce additional control variables, exclude parliaments with high numbers of observations, and exclude clearly insignificant variables. Here, we focus on the effect of ambition; detailed results including the estimates for the other variables are available in the appendix.

Figure 5 displays the coefficients for the progressive ambition variable along with the $95 \%$ confidence intervals in the different models. The coefficient estimates from the main models, discussed in the previous section, are presented at the top of the plots and indicated by the vertical grey lines. First, we test three alterative measures of progressive ambition. The first one codes Belgian regional MPs aiming for the national parliament as having static instead of progressive ambition because one can argue that moving to the national level is no longer a step up in the career 

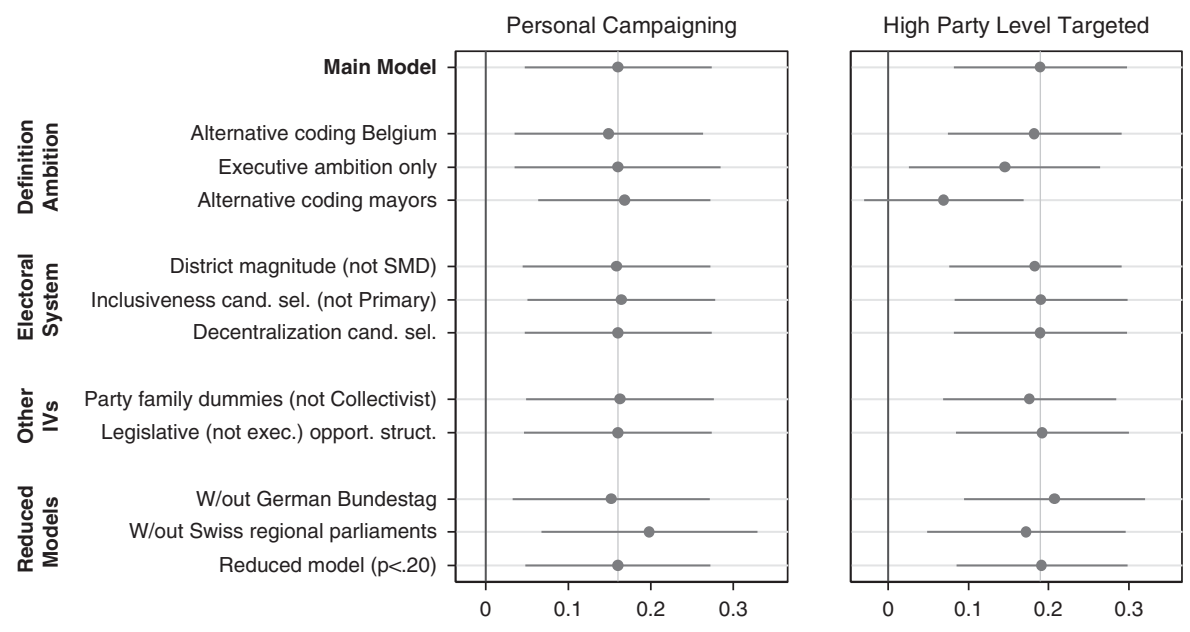

Figure 5 Robustness tests II: The effect of progressive ambition in alternative model specifications. Regression coefficient of the variable Progressive Ambition with 95\% CI. The thin vertical lines indicate the coefficient value in the main model.

ladder in Belgium. The second treats only MPs aspiring to executive office (not parliamentary office on the national level) as progressively ambitious. The third one also codes mayoral aspirants as progressively ambitious because these positions sometimes command sizeable budgets and high prestige. These alternatives yield largely similar results. The only difference is that ambition is no longer significant for the party level targeted if mayoral ambition is treated as progressive. As mayoral candidates are usually nominated at the local level, this finding provides additional support for our general argument that progressively ambitious MPs target the selectorate that is the most important for realizing their future career goals.

Second, we employ three alternative operationalization of electoral system variables: a continuous variable district magnitude instead of the binary variable single member district; a categorical measure of the inclusiveness of candidate selection procedure that distinguishes between selection by party leaders, selection by party agencies, and party primaries instead of only focusing on the latter; and an additional variable that controls for the decentralization of candidate selection (national or regional level vs. local or district level) as the second conceptual dimension identified by Hazan and Rahat (2010). None of these changes affect the coefficient for progressive ambition. Furthermore, the effects of the electoral system variables (not shown here; see appendix) stay largely the same even though the variables fail to reach established levels of statistical significance in some alternative specifications. The only stark difference is that the continuous measure for district magnitude has no effect on personalized campaigning in contrast to the positive effect of single member districts. This finding supports our theoretical argument for using the binary distinction between single member and multi member districts, 
according to which increases in district magnitude do not have a consistent effect for higher values of the variable.

Third, we use different operationalizations for two other independent variables. As our grouping of party families into collectivist versus individualist may be controversial in some instances, we rerun the models with a set of dummy variables for the 12 party families distinguished in the data set. The effects of ambition remain unchanged. Furthermore, the coefficients of the dummy variables support our coding: Compared to Social Democratic parties as the model baseline, agrarian MPs, Christian Democrats, Conservatives and Liberals are significantly more likely to favor personalized campaigns, whereas members of Green parties focus significantly on more party-centered campaigning. The other parties (Communists, regional parties, religious parties, far-right parties, single-issue parties and the residual category) do not differ significantly from the Social Democrats. Furthermore, we control for the opportunity structure within a parliament instead of the availability of cabinet positions by using the ratio of the number of committees (and thus committee chairs) to the total number of MPs in a parliament. This alternative operationalization does not affect the coefficient of the ambition variable and the effect of the opportunity structure remains substantively similar, although it narrowly misses statistical significance in the model on the party level targeted (see appendix).

Fourth, we test whether our results are driven by the largest parliament in the sample (the German Bundestag) or the large number of MPs from the various regional parliaments in Switzerland. Excluding either group of MPs does not substantively alter our findings even though the effect of progressive ambition is slightly stronger for personalized campaigning and weaker for the party level targeted without Swiss regional MPs. Finally, we re-estimate our models in a reduced specification excluding clearly insignificant variables $(p>0.20)$ in a stepwise process. The findings for progressive ambition (and all other explanatory variables; see appendix) remain the same.

Fifth, estimating the models as multi-level ordinal logistic regressions instead of employing a linear model leads to substantively equivalent results (see appendix).

\section{Conclusion}

Despite the theoretical importance of ambition for rational choice theories of parliamentary behavior, we lack systematic knowledge about the types of ambition MPs in party-centered parliamentary democracies hold and about how this ambition affects their strategies and behavior. In this paper, we took first steps toward filling these gaps. Theoretically, we identified individual visibility as a unifying goal of progressively ambitious MPs irrespective of the institutional and political context in which they operate. Individual visibility is vital in the competition for higher positions as MPs must stand out from the crowd and prove their leadership ability to their parties as the most important selectorate. Based on this insight, we hypothesized 
that ambitious MPs should be more interested in conducting personal instead of party-centered campaigns and should concentrate on mobilizing support from the party leadership at a higher level instead of focusing primarily on their local party. In addition, we formulated hypotheses on the effects of various electoral system features that provide MPs with different incentives to ensure their reelection as well as party ideology.

Descriptively, we provided the first comparative overview of the types of ambition held by European and Israeli MPs based on the comparative MP survey PartiRep. We found that progressive ambition is widespread and is more frequently found on the subnational level. Furthermore, observed country patterns suggest that its prevalence is linked to the institutional opportunity structure for promotion and the attractiveness of parliament, but these patterns require more systematic analysis in the future.

We tested our theoretical hypotheses using a three-level hierarchical linear regression model. As expected, progressively ambitious MPs voice more support for personal campaigns and for seeking the backing of the national or regional party leadership that is essential for promotion to higher offices. Reelection incentives are also operative for all MPs irrespective of ambition, leading to more support for personal campaigns and a stronger focus on the local party by MPs in systems with single member districts, candidate votes, and primaries. Finally, a collectivist party ideology is associated with more party-centered campaigning. Various additional specifications demonstrated the robustness of our findings.

While our findings speak to the importance of ambition in explaining MPs' strategies, they are somewhat limited due to their focus on attitudinal measures of how MPs state they would balance competing goals regarding campaign style and targeting different levels of their party. These measures provide a very direct link to ambition and are somewhat isolated from considerations about the institutional opportunity structure and the resulting chances of actually attaining higher office. Thus they provide strong internal validity. As a downside, however, it remains unclear to what extent these attitudinal differences translate into differences in behavior. Thus, the external validity of our findings beyond the level of attitudes remains an item for future study.

Investigating how progressive ambition shapes the observed behavior of MPs is thus the logical next step from the present study. Do progressively ambitious MPs engage in more individualized behavior? Does individualized behavior increase their likelihood for advancement? How does the party leadership react to such behavior? And finally, how is the translation of ambition into behavior, both within and beyond the parliamentary arena, shaped by the institutional opportunity structure they face? Unfortunately, these questions cannot be answered with the survey data at hand. Instead, their analysis requires behavioral data (ideally linked to survey responses) that can be validly applied across different institutional contexts. While the PartiRep data set contains some measures of legislative activity such as sponsoring bills and asking questions, the relevant variables contain many 
missing values and the comparability of the measures across parliaments is open to debate. Collecting comparable behavioral legislative data and connecting it to individual MPs and their attitudes is certainly a daunting task. However, as individual ambition provides a central starting point for analyzing parliamentary behavior from an individualistic perspective, we consider it a worthwhile avenue for future research on MPs in parliamentary democracies.

\section{Acknowledgments}

This research has benefited from financial support by the Zukunftskolleg of the University of Konstanz granted to Ulrich Sieberer and two grants to Wolfgang C. Müller from the Jubiläumsfonds of the Oesterreichische Nationalbank (Project Nr. 12057) and from the Austrian Research Fund (FWF) (Project Austrian National Election Study: The Supply Side: S10903-G11). An earlier version of this paper was presented at the workshop 'Understanding Parliamentarians' at the 2013 ECPR Joint Sessions of Workshops in Mainz. The authors gratefully acknowledge helpful comments and suggestions by Sam Depauw, Sven-Oliver Proksch, Thomas Saalfeld, other workshop participants, and three anonymous reviewers.

\section{Supplementary material}

To view supplementary material for this article, please visit http://dx.doi.org/ 10.1017/S1755773915000260

\section{References}

Abramson, P.R., J.H. Aldrich and D.W. Rohde (1987), 'Progressive ambition among United States senators: 1972-1988, Journal of Politics 49(1): 3-35.

André, A., A. Freire and Z. Papp (2014), 'Electoral rules and legislators' personal vote-seeking', in K. Deschouwer and S. Depauw (eds), Representing the People. A Survey Among Members of Statewide and Substate Parliaments, Oxford: Oxford University Press, pp. 87-109.

Bernauer, J. and T. Bräuninger (2009), 'Intra-party preference heterogeneity and faction membership in the 15th German bundestag: a computational text analysis of parliamentary speeches', German Politics 18(3): 385-402.

Cain, B., J. Ferejohn and M.P. Fiorina (1987), The Personal Vote. Constituency Service and Electoral Independence, Cambridge: Harvard University Press.

Carey, J.M. (2007), 'Competing principals, political institutions, and party unity in legislative voting', American Journal of Political Science 51(1): 92-107.

Carey, J.M. and M.S. Shugart (1995), 'Incentives to cultivate a personal vote: a rank ordering of electoral formulas', Electoral Studies 14(4): 417-439.

Cox, W.G., F.M. Rosenbluth and M.F. Thies (2000), 'Electoral rules, career ambitions, and party structure: comparing factions in Japan's upper and lower houses', American Journal of Political Science 44(1): 115-122.

Dalton, R.J. and M.P. Wattenberg (eds) (2000), Parties without Partisans. Political Change in Advanced Industrial Democracies, Oxford: Oxford University Press. 
Debus, M. and H. Bäck (2014), 'Der Einfluss von Mandatstyp und Wahlkreiseigenschaften auf die inhaltlichen Positionen in Parlamentsreden. Eine Untersuchung anhand der parlamentarischen Debatten im Deutschen Bundestag von 1998 bis 2002', Swiss Political Science Review 20(2): 330-353.

Deschouwer, K. and S. Depauw (eds) (2014), Representing the People. A Survey Among Members of Statewide and Substate Parliaments, Oxford: Oxford University Press.

Deschouwer, K., S. Depauw and A. André (2014), 'Representing the people in parliaments', in K. Deschouwer and S. Depauw (eds), Representing the People. A Survey Among Members of Statewide and Sub-state Parliaments, Oxford: Oxford University Press, pp. 1-18.

Döring, H. and P. Manow (2012), Parliament and government composition database (ParlGov): An Infrastructure for Empirical Information on Parties, Elections and Governments in Modern Democracies, Version 12/10: parlgov.org (accessed January 15, 2013).

Downs, A. (1957), An Economic Theory of Democracy, New York: Harper \& Row.

Epstein, D., D. Brady, S. Kawato and S. O'Halloran (1997), 'A comparative approach to legislative organization: careerism and seniority in the United States and Japan', American Journal of Political Science 41(3): 965-998.

Gelman, A. and J. Hill (2007), Data Analysis Using Regression and Multilevel Hierarchical Models, Cambridge: Cambridge University Press.

Giannetti, D. and K. Benoit (eds) (2009), Intra-party Politics and Coalition Governments, London: Routledge.

Hazan, R.Y. and G. Rahat (2010), Democracy Within Parties. Candidate Selection Methods and Their Political Consequences, Oxford: Oxford University Press.

Heller, W.B. and C. Mershon (eds) (2009), Political Parties and Legislative Party Switching, Houndmills: Palgrave Macmillan.

Herrick, R. and M.K. Moore (1993), 'Political ambition's effect on legislative behavior: Schlesinger's typology reconsidered and revised', Journal of Politics 55(3): 765-776.

Hibbing, J.R. (1986), 'Ambition in the house: behavioral consequences of higher office goals among U.S. representatives', American Journal of Political Science 30(3): 651-665.

Kam, C.J. (2009), Party Discipline and Parliamentary Politics, Cambridge: Cambridge University Press.

Karvonen, L. (2010), The Personalisation of Politics. A Study of Parliamentary Democracies, Colchester: ECPR Press.

Maestas, C. (2003), 'The incentives to listen: progressive ambition, resources, and opinion monitoring among state legislators', Journal of Politics 65(2): 439-456.

Maestas, C.D., S. Fulton, L.S. Maisel and W.J. Stone (2006), 'When to risk it? Institutions, ambitions, and the decision to run for the U.S. House', American Political Science Review 100(2): 195-208.

Martin, S. (2010), 'Electoral rewards for personal vote cultivation under PR-STV', West European Politics 33(2): 369-380.

— (2014), 'Why electoral systems don't always matter: the impact of "mega-seats" on legislative behavior in Ireland', Party Politics 20(1): 467-479.

Mayhew, D.R. (1974), Congress. The Electoral Connection, New Haven, CT: Yale University Press.

Meserve, S.A., D. Pemstein and W.T. Bernhard (2009), 'Political ambition and legislative behavior in the European Parliament', Journal of Politics 71(3): 1015-1032.

Micozzi, J.P. (2014), 'Alliance for progress? Multilevel ambition and patterns of cosponsorship in the Argentine House', Comparative Political Studies 47(8): 1186-1208.

Müller, W.C. (2000), 'Political parties in parliamentary democracies. Making delegation and accountability work', European Journal of Political Research 34(3): 309-333.

Müller, W.C. and K. Strøm (eds) (1999), Policy, Office, or Votes? How Political Parties in Western Europe Make Hard Decisions, Cambridge: Cambridge University Press.

Norris, P. (ed.) (1997), Passages to Power. Legislative Recruitment in Advanced Democracies, Cambridge: Cambridge University Press.

O'Brian, D.Z. and Y. Shomer (2013), 'A cross-national analysis of party switching', Legislative Studies Quarterly 38(1): 111-141.

Ozbudun, E. (1970), 'Party cohesion in western democracies: a causal analysis', Sage Professional Papers in Comparative Politics 1(6): 303-388. 
Poguntke, T. and P.D. Webb (eds) (2005), The Presidentialization of Politics. A Comparative Study of Modern Democracies, Oxford: Oxford University Press.

Proksch, S. and J.B. Slapin (2012), 'Institutional foundations of legislative speech', American Journal of Political Science 56(3): 520-537.

Riker, W.H. (1962), The Theory of Political Coalitions, New Haven: Yale University Press.

Rohde, D.W. (1979), 'Risk-bearing and progressive ambition: the case of members of the United States house of representatives', American Journal of Political Science 23(1): 1-26.

Saalfeld, T. and K.W. Strøm (2014), 'Political parties and legislators', in S. Martin, T. Saalfeld and K.W. Strøm (eds), The Oxford Handbook of Legislative Studies, Oxford: Oxford University Press, pp. 371-398.

Samuels, D. (2003), Ambition, Federalism, and Legislative Politics in Brazil, Cambridge: Cambridge University Press.

Schlesinger, J.A. (1966), Ambition and Politics. Political Careers in the United States, Chicago: Rand McNally.

Schumpeter, J.A. (1942), Capitalism, Socialism and Democracy, New York: Harper \& Brothers.

Searing, D.D. (1994), Westminster's World. Understanding Political Roles, Cambridge: Harvard University Press.

Shomer, Y. (2014), 'What affects candidate selection processes? A cross-national examination', Party Politics 20(4): 533-546.

Sieberer, U. (2006), 'Party unity in parliamentary democracies: a comparative analysis', Journal of Legislative Studies 12(2): 150-178.

- (2010), 'Behavioral consequences of mixed electoral systems: deviating voting behavior of district and list MPs in the german bundestag', Electoral Studies 29(3): 484-496.

- (2015), 'Using MP statements to explain voting behavior in the German bundestag: an individual level test of the competing principals theory', Party Politics 21(2): 284-294.

Stratmann, T. and M. Baur (2002), 'Plurality rule, proportional representation, and the German Bundestag: how incentives to pork-barrel differ across electoral systems', American Journal of Political Science 46(3): 506-514.

Strøm, K. (1990), 'A behavioral theory of competitive political parties', American Journal of Political Science 34(2): 565-598.

- (1997), 'Rules, reasons, and routines: legislative roles in parliamentary democracies', Journal of Legislative Studies 3(1): 155-174.

Treul, S.A. (2009), 'Ambition and party loyalty in the U.S. Senate', American Politics Research 37(3): 449-464.

Van der Slik, J.R. and S.J. Pernacciaro (1979), 'Office ambitions and voting behavior in the U.S. Senate', American Politics Quarterly 7(2): 198-224.

Victor, J.N. (2011), 'Legislating versus campaigning: the legislative behavior of higher office-seekers', American Politics Research 39(1): 3-31.

Zittel, T. and T. Gschwend (2008), 'Individualised constituency campaigns in mixed-member electoral systems. Candidates in the 2005 German elections', West European Politics 31(5): 978-1003. 